\title{
Marine tephrochronology: a personal perspective
}

\author{
DAVID J. LOWE ${ }^{1,2}$ \\ ${ }^{1}$ School of Science, Faculty of Science and Engineering, University of Waikato, Private Bag \\ 3105, Hamilton, New Zealand 3240 \\ (e-mail:d.lowe@waikato.ac.nz) \\ ${ }^{2}$ President, International Focus Group on Tephrochronology and Volcanism (INTAV), \\ Hamilton, New Zealand
}

Citation:

Lowe, D.J. 2014. Marine tephrochronology: a personal perspective. In: Austin, W.E.N., Abbott, P.M., Davies, S.M., Pearce, N.J.G., Wastegård, S. (editors), "Marine Tephrochronology". Geological Society, London, Special Publications 398, http://dx.doi.org/10.1144/SP398.11

Final pre-publication manuscript 1 April, 2014 


\section{Introduction}

This special volume on marine tephrochronology is remarkable, and timely, because it marks a concerted step towards what might be informally termed 'phase 3 ' of a revolution in Quaternary geosciences that began around 40 years ago. The ten articles collectively represent a re-focussed examination of tephras and cryptotephras preserved in ocean sediments at various locations and the authors describe their significance for a range of subdisciplines. Eight provide a new understanding of the origin, distribution, and ages of various tephra and cryptotephra deposits and their stratigraphic inter-relationships; how the terrestrial ages of the tephra/crypotephra deposits relate to those of enclosing sediments and inform the ongoing development of the marine radiocarbon time-scale; mechanisms for the emplacement, remobilisation, or bioturbation of the tephras or cryptotephras; and volcanic eruption history. Two further articles document the characterization of tephra-derived glass shards using microbeam techniques to analyse 30-40 elements from individual shards as small as $10 \mu \mathrm{m}$ in diameter. The collection thus provides snapshots of many aspects of the latest developments and directions in tephra studies - volcanology, primary and secondary dispersal, stratigraphy, single-grain characterization, chronology - through the medium of marine sediments. My personal perspective reflects briefly on how this point was reached and identifies a few of the important milestones on the way from 'phase 1 ' to 'phase 3 '. I am privileged to write it. 


\section{Marine science revolution}

As an undergraduate in the early-mid 1970s, I recall my first real 'awakening' regarding the dynamic nature of science, and of Quaternary geoscience in particular, when told about deep-sea core V28-238 from the equatorial Pacific Ocean (Shackleton \& Opdyke 1973) (>2650 citations, Google Scholar). Analogous to the opening notes of Beethoven's $5^{\text {th }}$ Symphony, perhaps the most famous quartet of notes in history, the alpha-numerical assemblage 'V28-238' is possibly the most instantly-recognizable abbreviation in Quaternary science (' $\mathrm{V}$ ' stands for Vema, the three-masted coring schooner of the Lamont Geological Observatory, now the Lamont-Doherty Earth Observatory of Columbia University). Lecturers Michael Selby and Cam Nelson (both now retired) at the University of Waikato, New Zealand, strongly emphasised the importance of V28-238, and of the deep-sea marine record in general, in developing a much more comprehensive understanding of changes in the Quaternary than previously attained. Although the modern phase of deep-sea drilling began in the 1950s, the formative findings emerging in the 1970s, including those of Hays et al. (1976) (>2800 citations, Google Scholar) have, rightly, been regarded as revolutionary (Walker \& Lowe, 2007). At this time, remember, the substantive theory of 'plate tectonics' was barely a decade old, and articles were still being published regularly on the correlation of on-land terrace sequences with the so-called 'four main Pleistocene glacial episodes'. In their discussion on the chronology of V28-238, Shackleton \& Opdyke $(1973$, p. 49) recorded the potential of tephrochronology by commenting on the usefulness of an Italian tephra (a 'Tuff with Black Pumices'): "If this eruption could be confidently placed in a climatic sequence, it is possible that it could be used to render our chronology even more accurate." 
The sense of discovery and the dramatic new world of possibilities that had opened up with the marine-based research continued in the 1980s when Cam Nelson took part as a ship-board scientist on the Glomar Challenger on Leg 90 (December 1982-January 1983) of the Deep-Sea Drilling Project (DSDP) that included coring in both the Tasman Sea and the Pacific Ocean immediately east of New Zealand (Fig. 1) (the final voyage of the Glomar Challenger, Leg 96, took place in October, 1983). Although not directly involved, it was exhilarating to be rubbing shoulders with Cam whilst he was working on material from the Leg 90 cores (Fig. 2). Cam and others including Chris Hendy, Paul Froggatt, and Kerry Black soon published several critically important papers, one showing for the first time synchroneity between long-term glacial and interglacial signals of both hemispheres and a 'genetic link' between alpine glaciation and the marine isotope record (from analyses of core sediments from the DSDP site 594) (Nelson et al. 1985a, 1986), another documenting a new spectral analysis procedure for dating Quaternary deep-sea sediments (Black et al. 1988), and several articles on the visible ('megascopic') tephra record preserved in the marine sediments (Nelson et al. 1985b; Froggatt et al. 1986) (Fig. 3). A startling find was that tephra deposits could be markedly thicker 'upwind' of source: ash ascending above $20 \mathrm{~km}$ altitude was carried directly westward towards the Tasman Sea by easterly stratospheric winds, while coeval lower-level ash was blown eastward ('downwind') of New Zealand into the southern Pacific Ocean (Nelson et al. 1985b). A second interesting result was the recognition that the visible tephras were only a fragmentary record of Quaternary volcanism in the southwest Pacific because New Zealand-derived silicic shards were a ubiquitous but disseminated minor component in many of the sediments in the cores. The disseminated glass shard concentrations, not visible as layers, today would be called cryptotephras (Lowe \& Hunt 2001; Lowe 2011). In addition, pale-green laminae <2 mm thick, 
common and conspicuous features in many of the cores examined (Fig. 4A), were inferred to represent diagenetically altered (mainly smectitic) remnant volcanic ash layers (Gardner et al. 1985).

This DSDP-based work thus revealed a compelling story about tephras but it was recognised clearly as being incomplete. Subsequent work on marine sediments in the southwest Pacific, which I have loosely denoted 'phase 2', expanded the Quaternary marine tephra record through analysis of cores obtained by various ships including the JOIDES Resolution (Ocean Drilling Program [ODP] followed by the Integrated ODP [IODP]), the Roger Revelle (Scripps Institute of Oceanography), the Marion Dufresne (French Polar Institute Paul-Emile Victor), and the New Zealand research vessel Tangaroa (e.g. Pillans \& Wright 1992; Carter et al. 1995, 2002, 2004; Alloway et al. 2005; Shane et al. 2006; Allan et al. 2008). The orbitally tuned chronology for the ODP/IODP cores, 'calibrated' or tested by numerical ages on tephras and magnetostratigraphy, provides an important framework for associated paleoenvironmental reconstructions (e.g. Carter 2005; Naish 2005; Holt et al. 2010; Alloway et al. 2013) (Fig. 4B). Tephras preserved in marine sedimentary sequences on land were also examined (e.g. Alloway et al. 1993; Naish et al. 1996; Shane et al. 1998; Pillans et al. 2005).

Phase 3 - delving into marine cryptotephras in the southwest Pacific region - has barely begun, as noted by Holt et al. (2011), although marine records and palaeoceanographic changes in the Australian and New Zealand regions, especially since 30,000 years ago, have now been documented and interpreted in some detail (e.g. Carter et al. 2008; Hayward et al. 2011; Newnham et al. 2012; Bostock et al. 2013; Marr et al. 2013; Nelson et al. 2013). 
Hence the work reported in this volume by Austin et al. (2014) on sediments in oceans of the Northern Hemisphere is at the forefront of marine tephra studies, and the authors and editors deserve credit and acclaim.

\section{Tephrochronological advances}

While the new tephra and palaeoenvironmental work in the marine realm was buzzing in the 1970s and 1980s, complementary advances were taking place on land in the discipline of physical volcanology, especially relating to explosive volcanism and its products (e.g. Walker 1973, 1983; Self \& Sparks 1981; Fisher \& Schminke 1984; Wilson \& Walker 1985; Wilson 1986, 1993), and in the thriving discipline of tephrochronology (e.g. Topping \& Kohn 1973; Westgate \& Fulton 1975; Machida \& Arai 1978; Smalley 1980; Lowe 1990). As well as studies on distal tephra deposits preserved in sediments, and in soils or palaeosols, new laboratory methods for characterizing the glass-shard and crystal (mineral) components of tephra deposits were being developed in a period of substantial technical advancement (e.g. Kohn 1970; Sarna-Wojcicki 1976; Westgate \& Gorton 1981; Beaudoin \& King 1986). These methods included the innovative use of the electron microprobe, developed mainly through the 1970 s and 1980s, to obtain major element compositions of individual glass shards rather than bulk samples (Smith \& Westgate 1968; Froggatt 1983, 1992; Hunt \& Hill 1996).Its advent in 1968 a stroke of brilliance, the microprobe method for glass analysis, initially criticised by some 'traditional' volcanic petrologists and geo-analysts, has been widely adopted today as the cornerstone analytical technique in tephra studies used alongside stratigraphic, chronological, and mineralogical data to help enable correlations to be made (Froese et al. 2008a; Lowe 2011). More recent refinements of the electron microprobe 
method for the analysis of glass shards or melt inclusions, or for crystals, include those described by Turney et al. (2004), Kuehn et al. (2011), Matsu'ura et al. (2011, 2012), Hayward (2012), Hall \& Hayward (2014), Marcaida et al. (2014), and Pearce et al. (2014). Subsequently, from the mid-1990s, the development of the laser-ablation inductively coupled plasma-mass spectrometric method for the analysis of trace elements in individual glass shards provided another dramatic leap forward in tephra analysis, especially those involving thin distal deposits or cryptotephras (e.g. Westgate et al. 1994, 2013a; Pearce et al. 2004, 2007, 2011; Tomlinson et al. 2010; Preece et al. 2011).

Alongside these methods of characterization, new or improved methods for dating tephras or cryptotephras have emerged, such as the isothermal plateau fission-track method for dating glass shards (Westgate 1989; Sandhu \& Westgate 1995; Westgate et al. 2013b). New ways of developing age models for tephra layers or cryptotephra deposits in sedimentary sequences using wiggle-matching or Bayesian statistical procedures (Buck et al. 2003) alongside radiocarbon, optical, ${ }^{40} \mathrm{Ar} /{ }^{39} \mathrm{Ar}$, or other dating methods have become very important as well in the past decade (e.g. Hogg et al. 2003, 2012; J. Lowe et al. 2007; Lowe et al. 2013; Blockley et al. 2008; Blaauw \& Christen 2011; Biswas et al. 2013; Smith et al. 2013). Methods by which tephras or cryptotephras could be correlated on a more quantitative basis using numerical or statistical analysis of their compositional data, along with other information such as stratigraphic position and relationship to other tephras or deposits, palaeoecological or archaeological associations, and numerical age, are currently being reviewed and evaluated.

Perhaps the most unexpected development during my career has been the flourishing of tephra studies in areas remote from volcanic sources through cryptotephra deposits (Lowe 2008). The rise of a new generation of cryptotephra specialists all around the 
world has been astounding. Given that my own early New Zealand work was on distal tephras, including studies on admixed 'non visible' tephras in buried soil sequences (e.g. Lowe 1986), I should perhaps have been more prescient! The advent of systematic studies of cryptotephras - the identification, correlation, mapping, and dating of sparse, finegrained glass-shard and/or crystal concentrations 'hidden' within sediments or soil - over the past 25 years since Andrew Dugmore's seminal (1989) paper has undoubtedly been revolutionary. Although new and increasingly efficacious techniques for cryptotephra detection, extraction, and identification were developed primarily in northwestern Europe and Scandinavia, and more lately North America (e.g. Turney 1998; Dugmore et al. 1992, 1995; Wastegård et al. 2000; Hall \& Pilcher 2002; Blockley et al. 2005; Gehrels et al. 2008; Payne et al. 2008; Kuehn \& Froese 2010; Pyne-O’Donnell et al. 2012), earlier work in New Zealand had demonstrated the occurrence of glass shards or crystals in concentrations not visible as layers in sedimentary deposits or soils. Robertson \& Mew (1982) were the first to count glass shards in soils developed on loess and glacial deposits in western South Island, writing (p. 506) ... "Although no distinct ash layers were observed in the West Coast soil profiles, it is probable that, as the amounts of glass present are low, such a layer would be difficult to detect in the field". The shards were subsequently identified as correlatives of the c. 25,400 cal. year-old Kawakawa tephra; 'cryptic' occurrences in loess elsewhere were also identified through glass-shard counting and major element analysis (Mew et al. 1986; Eden \& Froggatt 1988; Almond 1996; Vandergoes et al. 2013). Lowe et al. (1981) and Lowe (1988a) were among the first to use X-radiography to detect non-visible glass shard concentrations in peat and lake sediments and to characterize them using a rapid X-ray fluorescence technique, and Hogg \& McCraw (1983, p. 182) used the sparse occurrence of distinct (optically dark green) aegirine crystals in ash-derived soils and palaeosols to map c. 
7000 cal. year-old Tuhua tephra at least $80 \mathrm{~km}$ beyond its visible limits in the field (see also Table 2 in Lowe et al. 2008, p. 101).

The burgeoning cryptotephra methods, likened to 'forensic tephrochronology', have now been applied to terrestrial, ice-core, and marine sedimentary sequences in all parts of the world (e.g. see Table 1 in Lowe 2008, p. 315). Cryptotephras have been discovered in peat, lake, marine, and aeolian sediments (including frozen sediment, i.e. permafrost), in ice, in soils and palaeosols, and in deposits in caves. The tenacious cryptotephra studies, although not without serious limitations and problems such as taphonomic issues and quantitation uncertainties (especially when dealing with limited numbers of shards or crystals) (e.g. Payne et al. 2005; Davies et al. 2007; Lowe 2011; Pyne-O’Donnell 2011; Lane et al. 2014), have documented tephra-fall occurrences at sub-millimetre scale at distances spanning hundreds to thousands of kilometres (now described as 'ultra-distal'), greatly extending known geographical limits to $>7000$ km from source (e.g. Gehrels et al. 2006; Davies et al. 2008; Brendryen et al. 2010; Lawson et al. 2012; Pyne-O’Donnell et al. 2012; Lane et al. 2013).

\section{Marine cryptotephrochronology: the next revelatory revolution}

Returning to the main theme of this volume, the value of marine sediments in providing potentially very detailed records of tephra layers or cryptotephras, and their applications tephrochronologically, are now well recognised and exploited (e.g. Chun et al. 2007; Hillenbrand et al. 2008; Abbott et al. 2011, 2013; Cage et al. 2011; Albert et al. 2012; Gudmundsdóttir et al. 2012). As recognised by Nelson et al. (1985b), cores of marine sediment have the potential to provide a detailed stratigraphic record of tephra fallout 
because large proportions of volcanic eruptives are deposited in the sea (Cassidy et al. 2013). Together with terrestrial records such as those from lakes, bogs, and ice cores, the marine tephra or cryptotephra deposits can therefore help document patterns of explosive volcanism in time and space, often more comprehensively than those obtainable near volcanic eruption centres, and integrate the stratigraphic interfingering of eruptives from multiple volcanic sources (Lowe 1988b; Alloway et al. 2005; Shane 2005; Shane et al. 2006; Bourne et al. 2010, 2013; Davies et al. 2010; Lim et al. 2013; Ponomareva et al. 2013; Insinga et al. 2014).

Although distal deposits tend to be more restricted compositionally than their proximal counterparts generated from the same eruptive episode (e.g. Smith et al. 2005), recent work on magmatic heterogeneity at some volcanoes has shown that multiple fingerprints may arise according to tephra dispersal direction during a 'single' eruption episode, adding complexity and the need for a careful approach in making long-range correlations (Shane et al. 2008). Potential complications and, paradoxically, insights, thus abound especially in studying tephras and cryptotephras in the marine realm where reworking and bioturbation may be commonplace, and where 'anomalous' grain-size patterns may tell an unexpected story (e.g. Hunt et al. 1995; Lackschewitz \& WallrabeAdams 1997; Lacasse et al. 1998; Manville \& Wilson 2004; Ascough et al. 2005; Kristjánsdóttir et al. 2007; Todd et al. 2014).

Tephra studies globally are in an incredibly expansive and productive phase right now (e.g. Froese et al. 2008b; Lowe et al. 2011; Alloway et al. 2013; Gorbarenko et al. 2013; Smith 2013), with a number of specialist lab groups around the world leading the way in exemplary fashion. Tephra specialists (tephrochronologists) provide essential expertise in numerous projects where tephras or cryptotephras, commonly both, are key stratigraphic 
correlational, synchronizational, or dating tools to help meet the objectives of highresolution palaeoclimatic projects such as INTIMATE (Integration of ice-core, marine and terrestrial records to reconstruct past abrupt and extreme climate changes from 60,000 to 8000 years ago), SMART (Synchronising marine and ice-core records using tephrochronology), CELL50K (Calibrating environmental leads and lags over the last 50,000 years), TRACE (Tephra constraints on rapid climatic events), the Lake Suigetsu 2006 varved sediment-core project (Japan), and SHAPE (Southern Hemisphere assessment of palaeoenvironments). These and other projects (such as the RESET, Response of humans to abrupt environmental transitions), all involving tephrochronology, are meeting the challenge laid down for Quaternary scientists by Walker and Lowe (2007, p. 1087) "to generate integrated datasets of the highest possible quality and temporal resolution to provide meaningful baselines for predictive models of the global future." Tephras and crypotephras are also being identified and utilized in growing archaeological and palaeoanthropological studies (e.g. Wastegård \& Davies 2009; Housley et al. 2012; J. Lowe et al. 2012; Streeter et al. 2012; Riede \& Thastrup 2013; Lane et al. 2014).

\section{Conclusion}

This benchmark volume sets the scene for the development of the next phase of integrating marine science studies with tephrochronology. Tephra or cryptotephra deposits, usually in the form of glass shard concentrations at distal or ultra-distal sites, provide a chronostratigraphic link to equivalent deposits in other environments including the superlative ice-core records (e.g. Davies et al. 2008, 2010, 2014). Such work is already proving to be as stimulating as the breathtaking revelations 'hauled up' from the deep 
oceans $\sim 40$ years ago that helped to inspire several generations of Quaternary geoscientists, myself included.

It is perhaps instructive here to quote from a clever, insightful short essay by Schwartz (2008) on the need to seek answers by asking the right questions through what he termed 'productive stupidity' (p. 1171): “Productive stupidity means being ignorant by choice. Focusing on important questions puts us in the awkward position of being ignorant" and hence "The more comfortable we become with being stupid, the deeper we will wade into the unknown and the more likely we are to make big discoveries."

Always accompanied by the excitement and collegiality of discovery, and lifelong respect and friendship, much is promised and surely will be delivered as we wade deeper into the unknown through marine - and complementary terrestrial - tephrochronology and cryptotephrochronology.

\section{Acknowledgments}

I thank Nick Pearce for his invitation to contribute this article, and Helen Bostock, Cam Nelson, Siwan Davies, and John Hunt for reviewing it. Helpful comments from editors Bill Austin and Nick Pearce were also appreciated. Cam Nelson and Lionel Carter provided the figures, Elsevier gave me permission to use Fig. 4B, and Siwan Davies kindly furnished a pre-publication article. Ganqing Xu and Tim Ingle helped with the figures. This paper is an output of INTREPID Tephra-II (INQUA project 1307s) “Enhancing tephrochronology as a global research tool through improved fingerprinting and correlation techniques and uncertainty modelling", an initiative of the International Focus Group on Tephrochronology and Volcanism (INTAV) supported by the Stratigraphy and Chronology Commission (SACCOM) of the International Union for Quaternary Research (INQUA). 


\section{References}

ABBOTT, P. M., DAVIES, S. M., AUSTIN, W. E. N., PEARCE, N. J. G. \& HIBBERT, F. D. 2011. Identification of cryptotephra horizons in a north east Atlantic marine record spanning marine isotope stages 4 and 5a ( 60,000-82,000 a b2k). Quaternary International, 246, 177-189.

ABBOTT, P. M., AUSTIN, W. E. N., DAVIES, S. M., PEARCE, N. J. G. \& HIBBERT, F. D. 2013. Cryptotephrochronology of the Eemian and the last interglacial-glacial transition in the north-east Atlantic. Journal of Quaternary Science, 28, 501-514.

ALBERT, P. G., TOMLINSON, E. L., SMITH, V. C., DI ROBERTO, A., TODMAN, A., ROSI, M., MARANI, M., MULLER, W., \& MENZIES, M. A. 2012. Marine-continental tephra correlations: volcanic glass geochemistry from the Marsili Basin and the Aeolian Islands, southern Tyrrhenian Sea, Italy. Journal of Volcanology and Geothermal Research, 229-230, 74-94.

ALLAN, A. S. R., BAKER, J. A., CARTER, L. \& WYSOCZANKSI, R. J. 2008. Reconstructing the Quaternary evolution of the world's most active silicic volcanic system: insights from a 1.65 Ma deep ocean tephra record sourced from the Taupo Volcanic Zone, New Zealand. Quaternary Science Reviews, 27, 2341-2360.

ALLOWAY, B. V., PILLANS, B. J., SANDHU, A. S. \& WESTGATE, J. A. 1993. Revision of the marine chronology in Wanganui Basin, New Zealand, based on the isothermal plateau fission-track dating of tephra horizons. Sedimentary Geology, 82, 299-310.

ALLOWAY, B. V., PILLANS, B. J., CARTER, L., NAISH, T. \& WESTGATE, J. A. 2005. Onshoreoffshore correlation of Pleistocene rhyolitic eruptions from New Zealand: implications for 
TVZ eruptive history and paleoenvironmental construction. Quaternary Science Reviews,

24, 1601-1622.

ALLOWAY, B. V., LOWE, D. J., LARSEN, G., SHANE, P. A. R. \& WESTGATE, J. A. 2013.

Tephrochronology. In: ELIAS, S.A. \& MOCK, C.J. (eds) The Encyclopaedia of Quaternary Science, $2^{\text {nd }}$ edition, vol. 4. Elsevier, Amsterdam, 277-304.

ALMOND, P. C. 1996. Loess, soil stratigraphy and Aokautere Ash on Late Pleistocene surfaces in south Westland, New Zealand: interpretation and correlation with the glacial stratigraphy. Quaternary International, 34-36, 163-176.

ASCOUGH, P., COOK, G. \& DUGMORE, A. 2005. Methodological approaches to determining the marine radiocarbon reservoir effect. Progress in Physical Geography, 29, 532-547.

AUSTIN, W. E. N., ABBOTT, P. M., DAVIES, S. M., PEARCE, N. J. G. \& WASTEGÅRD, S. (eds) 2014. Marine Tephrochronology. Geological Society, London, Special Publications, 398.

BEAUDOIN, A. B. \& KING, R. H. 1986. Using discriminant function analysis to identify Holocene tephras based on magnetite composition: a case study from the Sunwapta Pass area, Jasper National Park. Canadian Journal of Earth Science, 2, 804-812.

BISWAS, R. H., WILLIAMS, M. A. J., RAJ, R., JUYAL, N. \& SINGHVI, A. K. 2013. Methodological studies on luminescence dating of volcanic ashes. Quaternary Geochronology, 17, 14-25.

BLAAUW, M. \& CHRISTEN, J. A. 2011. Flexible paleoclimate age-depth models using an autoregressive gamma process. Bayesian Analysis, 6, 457-474.

BLACK, K. P., NELSON, C. S. \& HENDY, C. H. 1988. A spectral analysis procedure for dating Quaternary deep-sea cores and its application to a high-resolution Bruhnes record from the souhwest Pacific. Marine Geology, 83, 21-30.

BLOCKLEY, S. P. E., PYNE-O’DONNELL, S. D. F., LOWE, J. J., MATTHEWS, I. P., STONE, A., POLLARD, A. M., TURNEY, C. S. M. \& MOLYNEUX, E. G. 2005. A new and less destructive 
laboratory procedure for the physical separation of distal glass tephra shards from sediments. Quaternary Science Reviews, 24, 1952-1960.

BLOCKLEY, S. P. E., BRONK RAMSEY, C., LANE, C. S. \& LOTTER, A. F. 2008. Improved age modelling approaches as exemplified by the revised chronology for the central European varved lake Soppensee. Quaternary Science Reviews, 27, 61-71.

BOSTOCK, H. C., BARROWS, T. T., CARTER, L., CHASE, Z., CORTESE, G., DUNBAR, G. B., ELLWOOD, M., HAYWARD, B., HOWARD, W., NEIL, H. L., NOBLE, T. L., MACKINTOSH, A., MOSS, P. T., MOY, A. D., WHITE, D., WILLIAMS, M. J. M. \& ARMAND, L. K. 2013. A review of the Australian-New Zealand sector of the Southern Ocean over the last 30 ka (AusINTIMATE project). Quaternary Science Reviews, 74, 35-57.

BOURNE, A. J., LOWE, J. J., TRINCARDI, F., ASIOLI, A., BLOCKLEY, S. P. E., WULF, S., MATTHEWS, I. P., PIVA, A. \& VIGLIOTTI, L. 2010. Distal tephra record of the last C. 105,000 years from core PRAD 1-2 in the central Adriatic Sea: implications for marine tephrostratigraphy. Quaternary Science Reviews, 29, 3079-3094.

BOURNE, A. J., DAVIES, S. M., ABBOTT, P. M., RASMUSSEN, S. O., STEFFENSEN, J. P. \& SVENSSON, A. 2013. Revisiting the Faroe Marine Ash Zone III in two Greenland ice cores: implications for marine-ice correlations. Journal of Quaternary Science, 28, 641-646. BRENDRYEN, J., HAFLIDASON, H. \& SEJRUP, H. P. 2010. Norwegian Sea tephrostratigraphy of marine isotope stages 4 and 5: prospects and problems for tephrochronology in the North Atlantic region. Quaternary Science Reviews, 29, 847-864.

BUCK, C. E., HIGHAM, T. F. G. \& LOWE, D. J. 2003. Bayesian tools for tephrochronology. The Holocene, 13, 639-647. 
CAGE, A. G., DAVIES, S. M., WASTEGÅRD, S. \& AUSTIN, W. E. N. 2011. Identification of the Icelandic Landnám tephra (AD $871 \pm 2$ ) in Scottish fjordic sediment. Quaternary International, 246, 168-176.

CARTER, R. M. 2005. A New Zealand climate template back to c. 3.9 Ma: ODP Site 1119, Canterbury Bight, south-west Pacific Ocean, and its relationship to onland successions. Journal of the Royal Society of New Zealand, 35, 9-42.

CARTER, L., NELSON, C. S., NEIL, H. L. \& FROGGATT, P. C. 1995. Correlation, dispersal, and preservation of the Kawakawa Tephra and other late Quaternary tephra layers in the southwest Pacific Ocean. New Zealand Journal of Geology and Geophysics, 38, 29-46. CARTER, L., MANIGHETTI, B., ELLIOT, M., TRUSTRUM, N. \& GOMEZ, B. 2002. Source, sea level and circulation effects on the sediment flux to the deep ocean over the past $15 \mathrm{ka}$ off eastern New Zealand. Global and Planetary Change, 33, 339-355.

CARTER, L., ALLOWAY, B. V., SHANE, P. \& WESTGATE, J. A. 2004. Deep-ocean record of major late Cenozoic rhyolitic eruptions from New Zealand. New Zealand Journal of Geology and Geophysics, 47, 481-500.

CARTER, L., MANIGHETTI, B., GANSSEN, G. \& NORTHCOTE, L. 2008. Southwest Pacific modulation of abrupt climate change during the Antarctic Cold Reversal-Younger Dryas. Palaeogeography, Palaeoclimatology, Palaeoecology, 260, 284-298.

CASSIDY, M., TROFIMOVS, J., PALMER, M. R., WATT, S. F. L. \& SYMONS, W. 2013. Cores for concern: the difficulty of recording tephra fallout deposits in marine sediments. Abstracts, IAVCEI 2013 Scientific Assembly (20-24 July), Kagoshima, Japan, 912.

CHUN, J.-H., CHEONG, D., IKEHARA, K. \& HAN, S.-J. 2007. Age of the SKP-I and SKP-II tephras from the southern East Sea/Japan Sea: implications for interstadial events recorded in 
sediment from marine isotope stages 3 and 4. Palaeogeography, Palaeoclimatology, Palaeoecology, 247, 100-114.

DAVIES, S. M., ELMQUIST, M., BERGMAN, J., WOHLFARTH, B. \& HAMMARLUND, D. 2007. Cryptotephra sedimentation processes within two lacustrine sequences from west central Sweden. The Holocene, 17, 319-330.

DAVIES, S. M., WASTEGÅRD, S., RASMUSSEN, T. L., SVENSSON, A., JOHNSEN, S. J., STEFFENSEN, J. P. \& ANDERSEN, K. K. 2008. Identification of the Fugloyarbanki tephra in the NGRIP ice core: a key tie-point for marine and ice-core sequences during the last glacial period. Journal of Quaternary Science, 23, 409-414.

DAVIES, S. M., WASTEGÅRD, S., ABBOTT, P. M., BARBANTE, C., BIGLER, M., JOHNSEN, S. J., RASMUSSEN, T. L., STEFFENSEN, J. P. \& SVENSSON, A. 2010. Tracing volcanic events in the NGRIP ice-core and synchronising North Atlantic marine records during the last glacial period. Earth and Planetary Science Letters, 294, 69-79.

DAVIES, S. M., ABBOTT, P. M., MEARA, R. H., PEARCE, N. J. G., AUSTIN, W. E. N., CHAPMAN, M. R., SVENSSON, A., BIGLER, M. \& RASMUSSEN, T. 2014. A North Atlantic tephrostratigraphic framework for 130,000 to 60,000 years b2k: new tephra discoveries, marine based-correlations, and future challenges. Quaternary Science Reviews (in press). DUGMORE, A. J. 1989. Icelandic volcanic ash in Scotland. Scottish Geographical Magazine, $105,168-172$

DUGMORE, A. J., LARSEN, G., NEWTON, A. J. \& SUGDEN, D. E. 1992. Geochemical stability of fine-grained silicic Holocene tephra in Iceland and Scotland. Journal of Quaternary Science, 7, 173-183.

DUGMORE, A. J., LARSEN, G. \& NEWTON, A. J. 1995. Seven tephra isochrones [sic] in Scotland. The Holocene, 5, 257-266. 
EDEN, D. N. \& FROGGATT, P. C. 1988. Identification and stratigraphic significance of distal Aokautere Ash in three cores from eastern South Island, New Zealand. In: EDEN, D. N. \& FURKERT, R. J. (eds) Loess: Its Distribution, Geology and Soils. A. A. Balkema, Rotterdam, 47-58.

FISHER, R. V. \& SCHMINKE, H.- U. 1984. Pyroclastic Rocks. Springer-Verlag, Berlin-Heidelberg. FROESE, D. G., ALLOWAY, B. V. \& LOWE, D. J. 2008a. John A. Westgate - global tephrochronologist, stratigrapher, mentor. Quaternary International, 178, 4-9.

FROESE, D. G., LOWE, D. J., KNOTT, J. \& SLATE, J. L. 2008b. Global tephra studies: John Westgate and Andrei Sarna-Wojcicki commemorative volume. [Preface.] Quaternary International, 178, 1-3.

FROGGATT, P. C. 1983. Toward a comprehensive Upper Quaternary tephra and ignimbrite stratigraphy in New Zealand using electron microprobe analysis of glass shards. Quaternary Research, 19, 188-200.

FROGGATT, P. C. 1992. Standardization of the chemical analysis of tephra deposits. Report of the ICCT working group. Quaternary International, 13-14, 93-96.

FROGGATT, P. C., NELSON, C. S., CARTER, L., GRIGGS, G. \& BLACK, K. P. 1986. An exceptionally large late Quaternary eruption from New Zealand. Nature, 319, 578-582. GARDNER, J. V., NELSON, C. S. \& BAKER, P. A. 1985. Distribution and character of pale green laminae in sediment from Lord Howe Rise: a probable late Neogene and Quaternary tephrostratigraphic record. In: KENNETT, J. P. \& VON DER BORCH, C. C. (eds) Initial Reports of the Deep Sea Drilling Project, 90. Ocean Drilling Program, Texas A \& M University, College Station, TX, 1145-1159. 
GEHRELS, M. J., LOWE, D. J., HAZELL, Z. J. \& NEWNHAM, R. M. 2006. A continuous 5300-yr Holocene cryptotephrostratigraphic record from northern New Zealand and implications for tephrochronology and volcanic hazard assessment. The Holocene, 16, 173-187.

GEHRELS, M. J., NEWNHAM, R. M., LOWE, D. J., WYNNE, S., HAZELL, Z. J. \& CASELDINE, C. 2008. Towards rapid assay of cryptotephra in peat cores: review and evaluation of various methods. Quaternary International, 178, 68-84.

GORBARENKo, S., CHEBYKIN, E. P., GOldBERG, E. L., STEPANOVA, O. G. \& LU, H. 2013. Chronicle of regional volcanic eruptions recorded in Okhotsk Sea sediments over the last 350 ka. Quaternary Geochronology, 20, 29-38.

GUDMUNDSDÓTTIR, E. R., EIRÍKSSON, J. \& LARSEN, G. 2012. Holocene marine tephrochronology on the Iceland shelf: an overview. Jökull, 62, 53-72.

HALL, V. A. \& PILCHER, J. R. 2002. Late Quaternary Icelandic tephras in Ireland and Great Britain: detection, characterization and usefulness. The Holocene, 12, 223-230.

HALL, M. \& HAYWARD, C. 2014. Preparation of micro- and crypto-tephras for quantitative microbeam analysis. In: AUSTIN, W. E. N., ABBOTT, P. M., DAVIES, S. M., PEARCE, N. J. G. \& WASTEGARD, S. (eds) Marine Tephrochronology. Geological Society, London, Special Publications, 398. First published online February 27, 2014. http://dx.doi.org/10.1144/SP398.5 (this volume).

HAYS, J. D., IMBRIE, J. \& SHACKLETON, N. J. 1976. Variations in the Earth's orbit: pacemaker of the ice ages. Science, 194, 1121-1132.

HAYWARD, C., 2012. High spatial resolution electron probe microanalysis of tephras and melt inclusions without beam-induced chemical modification. The Holocene, 22, 119-125. HAYWARD, B. W., SABAA, A. T., KOLODZIEJ, A., CRUNDWELL, M. P., STEPH, S., SCOTT, G. H., NEIL, H. L., BOSTOCK, H. C., CARTER, L. \& GRENFELL, H. R. 2011. Planktic foraminifera- 
based sea-surface temperature record in the Tasman Sea and history of the Subtropical Front around New Zealand, over the last one million years. Marine Micropaleontology, 82-83, $13-27$.

HILlenBRAND, C.- D., MORETON, S. G., CABURLOTTO, A., PUDSEY, C. J., LUCCHI, R. G., SMELLIE, J. L., BENETTI, S., GROBE, H., HUNT, J. B. \& LARTER, R. D. 2008. Volcanic time markers for Marine Isotopic Stages 6 and 5 in Southern Ocean sediments and Antarctic ice cores: implications for tephra correlations between palaeoclimatic records. Quaternary Science Reviews, 27, 518-540.

HOGG, A. G. \& MCCRAW, J. D. 1983. Late Quaternary tephras of Coromandel Peninsula, North Island, New Zealand: a mixed peralkaline and calkalkaline tephra sequence. New Zealand Journal of Geology and Geophysics, 26, 163-187.

HOGG, A. G., HIGHAM, T. F. G., LOWE, D. J., PALMER, J., REIMER, P. \& NEWNHAM, R. M. 2003. A wiggle-match date for Polynesian settlement of New Zealand. Antiquity, 77, 116125.

HOGG, A. G., LOWE, D. J., PALMER, J. G., BOSWIJK, G. \& BRONK RAMSEY, C. J. 2012. Revised calendar date for the Taupo eruption derived by ${ }^{14} \mathrm{C}$ wiggle-matching using a New Zealand kauri ${ }^{14} \mathrm{C}$ calibration data set. The Holocene, 22, 439-449.

HOLT, K., WALLACE, R. C., NEALL, V. E., KOHN, B. P. \& LOWE, D. J. 2010. Quaternary tephra marker beds and their potential for palaeoenvironmental reconstruction on Chatham Islands east of New Zealand, southwest Pacific Ocean. Journal of Quaternary Science, 25, 1169-1178.

HOLT, K. A., LOWE, D. J., HOGG, A. G. \& WALLACE, R. C. 2011. Distal occurrence of midHolocene Whakatane Tephra on the Chatham Islands, New Zealand, and potential for cryptotephra studies. Quaternary International, 246, 344-351. 
HOUSLEY, R. A., LANE, C. S., CULLEN, V. L., WEBER, .M.-J., RIEDE, F., GAMBLE, C. S. \& BROCK, F. 2012. Icelandic volcanic ash from the Late-glacial open-air archaeological site of Ahrenshöft LA 58 D, north Germany. Journal of Archaeological Science, 39, 708-716. HUNT, J. B. \& HILL, P. G. 1996. An inter-laboratory comparison of the electron probe microanalysis of glass geochemistry. Quaternary International, 34-36, 229-241.

HUNT, J. B., FANNIN, N. G. T., HILL, P. G. \& PEACOCK, J. D. 1995. The tephrochronology and radiocarbon dating of North Atlantic, Late-Quaternary sediments: an example from the St. Kilda Basin. Geological Society (London) Special Publications, 90, 227-248.

INSINGA, D. D., TAMBURRINO, S., ALIRER, F., VEZZOLI, L., BARRA, M., DE LANGE, G. J., TIEPOLO, M., VALLEFUOCO, M., MAZZOLA, S. \& SPROVIERI, M. 2014. Tephrochronology of the astronomically-tuned KCO1B deep-sea core, Ionian Sea: insights into the explosive activity of the central Mediterranean area during the last 200 ka. Quaternary Science Reviews, 85, 63-84

KOHN, B. P. 1970. Identification of New Zealand tephra layers by emission spectrographic analysis of their titanomagnetites. Lithos, 3, 361-368.

KOHN, B. P., PILLANS, B. J. \& MCGLONE, M. S. 1992. Zircon fission track age for Middle Pleistocene Rangitawa Tephra, New Zealand: stratigraphic and paleoclimatic significance. Palaeogeography, Palaeoclimatology, Palaeoecology, 95, 73-94.

KRISTJÁNSDÓTTIR, G. B., STONER, J. S., JENNINGS, A. E., ANDREWS, J. T. \& GRÖNVOLD, K. 2007. Geochemistry of Holocene cryptotephras from the North Iceland Shelf (MD992269): intercalibration with radiocarbon and paleomagnetic chronostratigraphies. The Holocene, 17, 155-176. 
KUEHN, S. C. \& FROESE, D. G. 2010. Tephra from ice - a simple method to routinely mount, polish, and quantitatively analyze sparse fine particles. Microscopy and Microanalysis, 16, 218-225.

KUEHN, S. C., FROESE, D. G., SHANE, P. A. R. \& INTAV INTERCOMPARISON PARTICIPANTS 2011. The INTAV intercomparison of electron-beam microanalysis of glass by tephrochronology laboratories: results and recommendations. Quaternary International, 246, $19-47$.

LACASSE, C., WERNER, R., PATERNE, M., SIGURDSON, H., CAREY, S. \& PINTE, G. 1998. Long range transport of Icelandic tephra to the Irminger Basin, Site 919. In: SAUNDERS, A.D., LARSEN, H.C. \& WISE JR., S.W. (eds) Proceedings of the Ocean Drilling Program Scientific Results, 152, 51-65.

LACKSCHEWITZ, K. S. \& WALLRABE-ADAMS, H.-J. 1997. Composition and origin of volcanic ash zones in Late Quaternary sediments from the Reykjanes Ridge: evidence for ash fallout and ice-rafting. Marine Geology, 136, 209-224.

LANE, C. S., CHORN, B. T. \& JOHNSON, T. C. 2013. Ash from the Toba supereruption in Lake Malawi shows no volcanic winter in East Africa at $75 \mathrm{ka}$. Proceedings of the National Academy of Sciences of the United States of America, 110, 8025-8029.

LANE, C. S., CULLEN, V. L., WHITE, D., BRAMHAM-LAW, C. W. F. \& SMITH, V. C. 2014. Cryptotephra as a dating and correlation tool in archaeology. Journal of Archaeological Science, 42, 42-50.

LAWSON, I. T., SWINDLES, G. T., PLUNKETT, G. \& GREENBERG, D. 2012. The spatial distribution of Holocene cryptotephras in north-west Europe since 7 ka: implications for understanding ash fall events from Icelandic eruptions. Quaternary Science Reviews, 41, $57-66$. 
LIM, C., TOYODA, K., IKEHARA, K. \& PEATE, D. W. 2013. Late Quaternary tephrostratigraphy of Baegdusan and Ulleung volcanoes using marine sediments in the Japan Sea/East Sea. Quaternary Research, 80, 76-87.

LOWE, D. J. 1986. Controls on the rates of weathering and clay mineral genesis in airfall tephras: a review and New Zealand case study. In: COLMAN, S. M. \& DETHIER, D. P. (eds) Rates of Chemical Weathering of Rocks and Minerals. Academic Press, Orlando, 265-330. LOWE, D. J. 1988a. Stratigraphy, age, composition, and correlation of late Quaternary tephras interbedded with organic sediments in Waikato lakes, North Island, New Zealand. New Zealand Journal of Geology and Geophysics, 31, 125-165.

LOWE, D. J. 1988b. Late Quaternary volcanism in New Zealand: towards an integrated record using distal airfall tephras in lakes and bogs. Journal of Quaternary Science, 3, 111120.

LOWE, D. J. 1990. Tephra studies in New Zealand: an historical review. Journal of the Royal Society of New Zealand, 20, 119-150.

LOWE, D. J. 2008. Globalization of tephrochronology: new views from Australasia. Progress in Physical Geography, 32, 311-335.

LOWE, D. J. 2011. Tephrochronology and its application: a review. Quaternary Geochronology, 6, 107-153.

LOWE, D. J. \& HUNT, J. B. 2001. A summary of terminology used in tephra-related studies. Les Dossiers de l'Archeo-Logis, 1, 17-22.

LOWE, D. J., HOGG, A. G. \& HENDY, C. H. 1981. Detection of thin tephra deposits in peat and organic lake sediments by rapid X-radiography and X-ray fluorescence techniques. Geology Department, Victoria University of Wellington Publication, 20, 74-77. 
LOWE, D. J., TIPPETT, J. M., KAMP, P. J. J., LIDDELL, I. J., BRIGGS, R. M. \& HORROCKS, J. L. 2001. Ages on weathered Plio-Pleistocene tephra sequences, western North Island, New Zealand. Les Dossiers de l'Archeo-Logis, 1, 45-60.

LOWE, J. J., BLOCKLEY, S. P. E., TRINCARDI, F., ASIOLI, A., CATTANEO, A., MATTHEWS, I. P., POLLARD, A. M. \& WULF, S. 2007. Age modelling of late Quaternary marine sequences in the Adriatic: towards improved precision and accuracy using volcanic event stratigraphy. Continental Shelf Research, 27, 560-582.

LOWE, D. J., SHANE, P. A. R., ALLOWAY, B. V. \& NEWNHAM, R. M. 2008. Fingerprints and age models for widespread New Zealand tephra marker beds erupted since 30,000 years ago: a framework for NZ-INTIMATE. Quaternary Science Reviews, 27, 95-126.

LOWE, D. J., DAVIES, S. M., MORIWAKI, H., PEARCE, N. J. G. \& SUZUKI, T. 2011. Enhancing tephrochronology and its application (INTREPID project): Hiroshi Machida commemorative volume. [Preface.] Quaternary International, 246, 1-5.

LOWE, J. J., BARTON, N., BLOCKLEY, S. P. E., BRONK RAMSEY, C., CULLEN, V. L., DAVIES, W., GAMBLE, C., GRANT, K., HARDIMAN, M., HOUSLEY, R., LANE, C. S., LEE, S., LEWIS, M., MACLEOD, A., MENZIES, M., MÜLlER, W., POLLARD, M., PRICE, C., ROBERTS, A. P., ROHLING, E. J., SATOW, C., SMITH, V. C., STRINGER, C. B., TOMLINSON, E. L., WHITE, D., ALBERT, P., ARIENZON, I., BARKER, G., BORIC, D., CARANDENTE, A., CIVETTE, L., FERRIER, C., GUADELLI, J.- L., KARKANAS, P., KOUMOUZELIS, M., MÜLLER, U. C., ORSI, G., PROSS, J., ROSI, M., SHALAMANOV-KOROBAR, L., SIRAKOV, N. \& TZEDAKIS, P. C. 2012. Volcanic ash layers illuminate the resilience of Neanderthals and early modern humans to natural hazards. Proceedings of the National Academy of Sciences of the United States of America, $109,13,532-13,537$. 
LOWE, D. J., BLAAUW, M., HOGG, A. G. \& NEWNHAM, R. M. 2013. Ages of 24 widespread tephras erupted since 30,000 years ago in New Zealand, with re-evaluation of the timing and palaeoclimatic implications of the Lateglacial cool episode recorded at Kaipo bog. Quaternary Science Reviews, 74, 170-194.

MACHIDA, H. \& ARAI, F. 1978. Akahoya Ash - a Holocene widespread tephra erupted from the Kikai caldera, south Kyushu. The Quaternary Research (Japan), 17, 143-163.

MANVILLE, V. \& WILSON, C. J. N. 2004. Vertical density currents: a review of their potential role in the deposition and interpretation of deep-sea ash layers. Journal of the Geological Society, London, 161, 947-958.

MARCAIDA, M., MANGAN, M. T., VAZQUEZ, J. A., BURSIK, M. \& LIDZBARSKI, M. I. 2014. Geochemical fingerprinting of Wilson Creek formation tephra layers (Mono Basin, California) using titanomagnetite compositions. Journal of Volcanology and Geothermal Research, 273, 1-14.

MARR, J. P., CARTER, L., BOSTOCK, H. C., SMITH, E. \& BOLTON, A. 2013. Southwest Pacific Ocean response to a warming world: using $\mathrm{Mg} / \mathrm{Ca}, \mathrm{Zn} / \mathrm{Ca}$ and $\mathrm{Mn} / \mathrm{Ca}$ in foraminifera to track surface ocean water masses during the last deglaciation. Paleoceanography, 28, 116.

MATTHEWS, N. E., SMITH, V. C., COSTA, A., DURANT, A. J., PYLE, D. M. \& PEARCE, N. J. G. 2012. Ultra-distal tephra deposits from super-eruptions: examples from Toba, Indonesia, and Taupo Volcanic Zone, New Zealand. Quaternary International, 258, 54-79.

MATSU'URA, T., UENO, T. \& FURUSAWA, A. 2011. Characterization and correlation of cryptotephras using major-element analyses of melt inclusions preserved in quartz in last interglacial marine sediments, southeastern Shikoku, Japan. Quaternary International, 246, 48-56. 
MATSU'URA, T., FURUSAWA, A. \& YANAGIDA, M. 2012. Detection and correlation of widespread cryptotephras in middle Pleistocene loess in NE Japan using cummingtonite geochemistry. Journal of Asian Earth Sciences, 60, 49-67.

MEW, G., HUNT, J. L., FROGGATT, P. C., EDEN, D. N. \& JACKSON, R. J. 1986. An occurrence of Kawakawa Tephra from the Grey River valley, South Island, New Zealand. New Zealand Journal of Geology and Geophysics, 29, 315-322.

NAISH, T. R. 2005. New Zealand's shallow-marine record of Pliocene-Pleistocene global sealevel and climate change. Journal of the Royal Society of New Zealand, 35, 1-8.

NAISH, T. R., KAMP, P. J. J., ALLOWAY, B. V., PILLANS, B. J., WILSON, G. S. \& WESTGATE, J. A. 1996. An integrated tephrochronology and magnetostratigraphy for cyclothemic marine strata, Wanganui Basin: implications for the Pliocene-Pleistocene boundary in New Zealand. Quaternary International, 34-36, 29-48.

NELSON, C. S., 1988. Revised age of a late Quaternary tephra at DSDP site 594 off eastern South Island and some implications for correlation. Geological Society of New Zealand Newsletter, 82, 35-40.

NELSON, C. S., HENDY, C. H., JARRETT, G. R. \& CUTHBERTSON, A. M. 1985a. Nearsynchroneity of New Zealand alpine glaciations and Northern Hemisphere continental glaciations during the past 750 kyr. Nature, 318, 361-363.

NELSON, C. S., FROGGATT, P. C. \& GOSSON, G. J. 1985b. Nature, chemistry, and origin of late Cenozoic megascopic tephras in Leg 90 cores from the southwest Pacific. In: KENNETT, J. P. \& VON DER BORCH, C. C. (eds) Initial Reports of the Deep Sea Drilling Project, 90. Ocean Drilling Program, Texas A \& M University, College Station, TX, 1160-1173. NELSON, C. S., HENDY, C. H., CUTHBERTSON, A. M. \& JARRETT, G. R. 1986. Late Quaternary carbonate and isotope stratigraphy, subantarctic Site 594, southwest Pacific. In: KENNETT, 
J. P. \& VON DER BORCH, C. C. (eds) Initial Reports of the Deep Sea Drilling Project, 90.

Ocean Drilling Program, Texas A \& M University, College Station, TX, 1425-1436.

NELSON, F. E., WILSON, G. S., NEIL, H. L. 2013. Marine magnetic signature of the Last Glacial Maximum and last deglaciation from the Southern Hemisphere mid-latitudes. Marine Geology, 346, 246-255.

NEWNHAM, R. M., VANDERGOES, M. J., SIKES, E., CARTER, L., WILMSHURST, J., LOWE, D. J., MCGLONE, M. S. \& SANDIFORD, A. 2012. Does the bipolar seesaw extend to the terrestrial southern mid-latitudes? Quaternary Science Reviews, 36, 214-222.

PAYNE, R. J., KILFEATHER, A. A., VAN DER MEER, J. J. M. \& BLACKFORD, J. J. 2005. Experiments on the taphonomy of tephra in peat. Suo, 56, 147-156.

PAYNE, R. J., BLACKFORD, J. \& VAN DER PLICHT, J. 2008. Using cryptotephras to extend regional tephrochronologies: an example from southeast Alaska and implications for hazard assessment. Quaternary Research, 69, 42-55.

PEARCE, N. J. G., WESTGATE, J. A., PERKINS, W. T. \& PREECE, S. J. 2004. The application of ICP-MS methods to tephrochronological problems. Applied Geochemistry, 19, 289-322. PEARCE, N. J. G., DENTON, J. S., PERKINS, W. T., WESTGATE, J. A. \& ALLOWAY, B. V. 2007. Correlation and characterisation of individual glass shards from tephra deposits using trace element laser ablation ICP-MS analyses: current status and future potential. Journal of Quaternary Science, 22, 721-736.

PEARCE, N. J. G., WESTGATE, J. A., PERKINS, W. T., \& WADE, S. C. 2011. Trace-element microanalysis by LA-ICP-MS: the quest for comprehensive chemical characterisation of single, sub-10 $\mu \mathrm{m}$ volcanic glass shards. Quaternary International, 246, 57-81.

PEARCE, N. J. G., ABBOTT, P. M. \& MARTIN-JONES, C. 2014. Microbeam methods for the analysis of glass in fine-grained tephra deposits: a SMART perspective on current and 
future trends. In: AUSTIN, W. E. N., ABBOTT, P. M., DAVIES, S. M., PEARCE, N. J. G. \& WASTEGÅRD, S. (eds) Marine Tephrochronology. Geological Society, London, Special Publications, 398. First published online February 27, 2014.

http://dx.doi.org/10.1144/SP398.1 (this volume).

PILLANS, B. J. \& WRIGHT, I. 1992. Late Quaternary tephrostratigraphy from the southern Havre Trough-Bay of Plenty, northeast New Zealand. New Zealand Journal of Geology and Geophysics, 35, 129-143.

PILLANS, B. J., KOHN, B. P., BERGER, G. W., FROGGATT, P. C., DULLER, G., ALLOWAY, B. V. \& HESSE, P. 1996. Multi-method dating comparison for mid-Pleistocene Rangitawa Tephra, New Zealand. Quaternary Science Reviews, 15, 641-653.

PILLANS, B. J., ALLOWAY, B. V., NAISH, T., ABBOTT, S. A., WESTGATE, J. A. \& PALMER, A. 2005. The distal archive of North Island silicic volcanism recorded in Pleistocene shallow marine sediments of Wanganui Basin, New Zealand. Journal of the Royal Society of New Zealand, 35, 43-90.

PONOMAREVA, V., PORTNYAGIN, M., DERKACHEV, A., PENDEA, L. F., BOURGEOIS, J., REIMER, P. J., GARBE-SCHONBERG, D., KRASHENINNIKOV, S. \& NURNBERG, D. 2013. Early Holocene $M^{\sim} 6$ explosive eruption from Plosky volcanic massif (Kamchatka) and its tephra as a link between terrestrial and marine paleoenvironmental records. International Journal of Earth Sciences, 102, 1673-1699.

PREECE, S. J., WESTGATE, J. A., FROESE, D. G., PEARCE, N. J. G. \& PERKINS, W. T. 2011. A catalogue of late Cenozoic tephra in the Klondike goldfields, Yukon. Canadian Journal of Earth Sciences, 48, 1386-1418.

PYNE-O'DONNELL, S. D. F. 2011. The taphonomy of Last Glacial-Interglacial Transition (LGIT) distal volcanic ash in small Scottish lakes. Boreas, 40, 131-145. 
PYNE-O’DONNELL, S. D. F., HUGHES, P. D. M., FROESE, D. G., JENSEN, B. J. L., KUEHN, S. C., MALLON, G., AMESBURY, M. J., CHARMAN, D. J., DALEY, T. J., LOADER, N. J., MAUQUOY, D., STREET-PERROTT, F. A. \& WOODMAN-RALPH, J. 2012. High-precision ultra-distal Holocene tephrochronology in North America. Quaternary Science Reviews, 52, 6-11. RIEDE, F. \& THASTRUP, M. D. 2013. Tephra, tephrochronology and archaeology - a (re)view from northern Europe. Heritage Science, 1 (15), 1-17.

ROBERTSON, S. M. \& MEW, G. 1982. The presence of volcanic glass in soils on the West Coast, South Island, New Zealand. New Zealand Journal of Geology and Geophysics, 25, 503-507.

SANDHU, A. S. \& WESTGATE, J. A. 1995. The correlation between reduction in fission-track diameter and areal track density in volcanic glass shards and its application in dating tephra beds. Earth and Planetary Science Letters, 131, 289-299.

SARNA-WOJCICKI, A. 1976. Correlation of late Cenozoic tuffs in the central Coast Ranges of California by means of trace- and minor-element chemistry. Geological Survey Professional Paper, 972, 1-30.

SCHWARTZ, M. A. 2008. The importance of stupidity in scientific research. Journal of Cell Science, 121, 1771.

SELF, S. \& SPARKS, R. S. J. (eds) 1981. Tephra Studies. Reidel, Dordrecht.

SHACKLETON, N. J. \& OPDYKE, N. D. 1973. Oxygen isotope and palaeomagnetic stratigraphy of equatorial Pacific core V28-238: oxygen isotope temperatures and ice volumes on a $10^{5}$ and $10^{6}$ year scale. Quaternary Research, 3, 39-55.

SHANE, P. A. R. 2005. Towards a comprehensive distal andesitic tephrostratigraphic framework for New Zealand based on eruptions from Egmont volcano. Journal of Quaternary Science, 20, 45-57. 
SHANE, P., BLACK, T., EGGINS, S. \& WESTGATE, J. A. 1998. Late Miocene marine tephra beds: recorders of rhyolitic volcanism in North Island, New Zealand. New Zealand Journal of Geology and Geophysics, 41, 165-178.

SHANE, P. A. R., SIKES, E. L. \& GUILDERSON, T. P. 2006. Tephra beds in deep-sea cores off northern New Zealand: implications for the history of Taupo Volcanic Zone, Mayor Island and White Island volcanoes. Journal of Volcanology and Geothermal Research, 154, 276290.

SHANE, P. A. R., NAIRN, I. A., MARTIN, S. B. \& SMITH, V. C. 2008. Compositional heterogeneity in tephra deposits resulting from the eruption of multiple magma bodies: implications for tephrochronology. Quaternary International, 178, 44-53.

SMALLEY, I. J. 1980. Volcanic ash southern style. Nature, 286, 841.

SMITH, V. C. 2013. Volcanic markers for dating the onset of the Anthropocene. In: WATERS, C. N., ZALASIEWICZ, J. A., WILLIAMS, M., ELLIS, M. A. \& SNELLING, A. M. (eds) A Stratigraphical Basis for the Anthropocene. Geological Society, London, Special Publications, 395, http://dx.doi.org/10.1144/SP395.11.

SMITH, D. G. W. \& WESTGATE, J. A. 1968. Electron probe technique for characterizing pyroclastic deposits. Earth and Planetary Science Letters, 5, 313-319.

SMITH, V. C., SHANE, P. A. R. \& NAIRN, I. A. 2005. Trends in rhyolite geochemistry, mineralogy, and magma storage during the last 50 kyr at Okataina and Taupo volcanic centres, Taupo Volcanic Zone, New Zealand. Journal of Volcanology and Geothermal Research, 148, 372-406.

SMITH, V. C., STAFF, R. A., BLOCKLEY, S. P. E., BRONK RAMSEY, C., NAKAGAWA, T., MARK, D. F., TAKEMURA, K., DANHARA, T. \& SUIGETSU 2006 PROJECT MEMBERS 2013. Identification and correlation of visible tephras in the Lake Suigetsu SG06 sedimentary 
archive, Japan: chronostratigraphic markers for synchronising of east Asian/west Pacific palaeoclimatic records across the last 150 ka. Quaternary Science Reviews, 67, 121-137. STREETER, R., DUGMORE, A. J. \& VÉSTEINSSON, O. 2012. Plague and landscape resilience in premodern Iceland. Proceedings of the National Academy of Sciences of the United States of America, 109, 3664-3669.

TODD, J. A., AUSTIN, W. E. \& ABBOTT, P. E. 2014. Quantifying bioturbation of a simulated ash fall event. In: AUSTIN, W. E. N., ABBOTT, P. M., DAVIES, S. M., PEARCE, N. J. G. \& WASTEGÅRD, S. (eds) Marine Tephrochronology. Geological Society, London, Special Publications, 398. First published online February 5, 2014. http://dx.doi.org/10.1144/SP398.9 (this volume).

TOMLINSON, E. L., THORDARSON, T., MÜLLER, W., THIRLWALL, M. F. \& MENZIES, M. A. 2010. Micro analysis of tephra by LA-ICP-MS - strategies, advantages and limitations assessed using the Thorsmork ignimbrite (Southern Iceland). Chemical Geology, 279, 7389.

TOPPING, W. W. \& KOHN, B. P. 1973. Rhyolitic tephra marker beds in the Tongariro area, North Island, New Zealand. New Zealand Journal of Geology and Geophysics, 16, 375-395. TURNEY, C. S. M. 1998. Extraction of rhyolitic component of Vedde microtephra from minerogenic lake sediments. Journal of Paleolimnology, 19, 199-206.

TURNEY, C. S. M., LOWE, J. J., DAVIES, S. M., HALL, V. A., LOWE, D. J., WASTEGÅRD, S., HOEK, W.Z. \& ALLOWAY, B. V. 2004. Tephrochronology of Last Termination sequences in Europe: a protocol for improved analytical precision and robust correlation procedures (a joint SCOTAV-INTIMATE proposal). Journal of Quaternary Science, 19, 111-120. VANDERGOES, M. J., HOGG, A. G., LOWE, D. J., NEWNHAM, R. M., DENTON, G. H., SOUTHON, J., BARRELL, D. J. A., WILSON, C. J. N., MCGLONE, M. S., ALLAN, A. S. R., 
ALMOND, P. C., PETCHEY, F., DALBELL, K., DIEFFENBACHER-KRALL, A. C. \& BLAAUW, M. 2013. A revised age for the Kawakawa/Oruanui tephra, a key marker for the Last Glacial Maximum in New Zealand. Quaternary Science Reviews, 74, 195-201.

WALKER, G. P. L. 1973. Explosive volcanic eruptions - a new classification scheme. Geologische Rundschau, 62, 431-446.

WALKER, G. P. L. 1983. Ignimbrite types and ignimbrite problems. Journal of Volcanology and Geothermal Research, 17, 65-88.

WASTEGÅRD, S. \& DAVIES, S. M. 2009. An overview of distal tephrochronology in northern Europe during the last 1000 years. Journal of Quaternary Science, 24, 500-512.

WASTEGÅRD, S., TURNEY, C. S. M., LOWE, J. J. \& ROBERTS, S. J. 2000. New discoveries of the Vedde Ash in southern Sweden and Scotland. Boreas, 29, 72-78.

WALKER, M. \& LOWE, J. J. 2007. Quaternary science 2007: a 50-year retrospective. Journal of the Geological Society, London, 164, 1073-1092.

WESTGATE, J. A. 1989. Isothermal plateau fission track ages of hydrated glass shards from silicic tephra beds. Earth and Planetary Science Letters, 95, 226-234.

WESTGATE, J. A. \& FULTON, R. J. 1975. Tephrostratigraphy of the Olympia interglacial sediments in southern British Columbia, Canada. Canadian Journal of Earth Sciences, 12, 489-502.

WESTGATE, J. A. \& GORTON, M. P. 1981. Correlational techniques in tephra studies. In: SELF, S. \& SPARKS, R. S. J. (eds) Tephra Studies. Reidel, Dordrecht, 73-94.

WeStgate, J. A., PERKINS, W. T., FUGE, R., PEARCE, N. J. G. \& WINTLE, A. G. 1994. Traceelement analysis of volcanic glass shards by laser ablation inductively coupled plasma mass spectrometry: application to tephrochronological studies. Applied Geochemistry, 9, 323-335. 
WeStgate, J. A., PEARCE, N. J. G., PERKInS, W. T., PREECE, S. J., CHESNER, C. A. \& MUHAMMAD, R. F. 2013a. Tephrochronology of the Toba tuffs: four primary glass populations define the 75 ka Youngest Toba Tuff, northern Sumatra, Indonesia. Journal of Quaternary Science, 28, 772-776.

WESTGATE, J. A., NAESER, N. D. \& ALLOWAY, B. V. 2013b. Fission-track dating. In: ELIAS, S. A. \& MOCK, C. J. (eds) The Encyclopaedia of Quaternary Science, $2^{\text {nd }}$ edition, vol. 1. Elsevier, Amsterdam, 643-662.

WILSON, C. J. N. 1986. Pyroclastic flows and ignimbrites. Science Progress (Oxford), 70, 171207.

WILSON, C. J. N. 1993. Stratigraphy, chronology, styles and dynamics of Late Quaternary eruptions from Taupo volcano, New Zealand. Philosophical Transactions of the Royal Society of London Series A, 343, 205-306.

WILSON, C. J. N. \& WALKER, G.P.L. 1985. The Taupo eruption, New Zealand I. General aspects. Philosophical Transactions of the Royal Society of London Series A, 314, 199-228. 


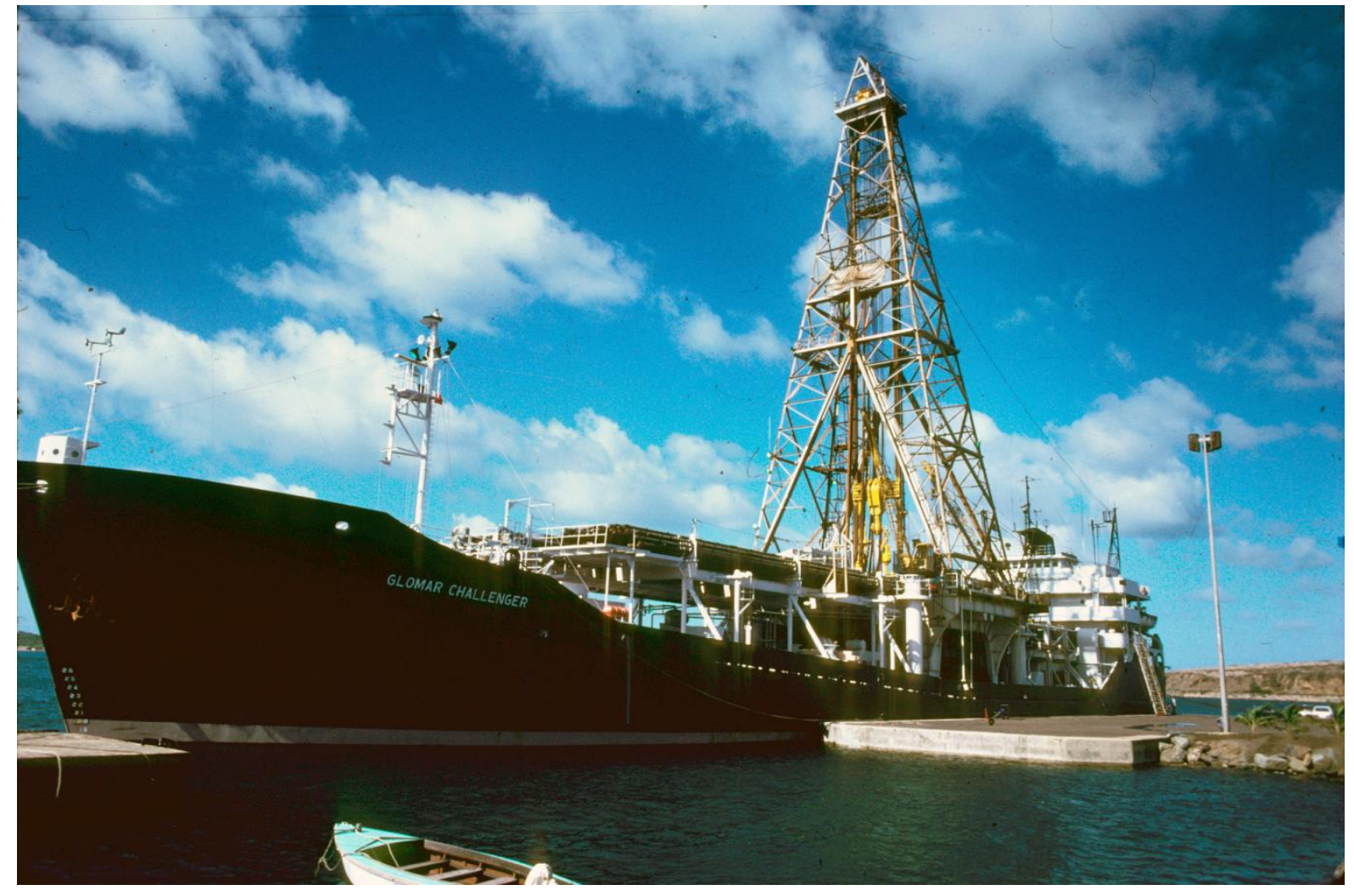

Fig. 1. The Glomar Challenger in Noumea in December, 1982, before embarking on DSDP Leg 90. Photo courtesy of Cam Nelson. 


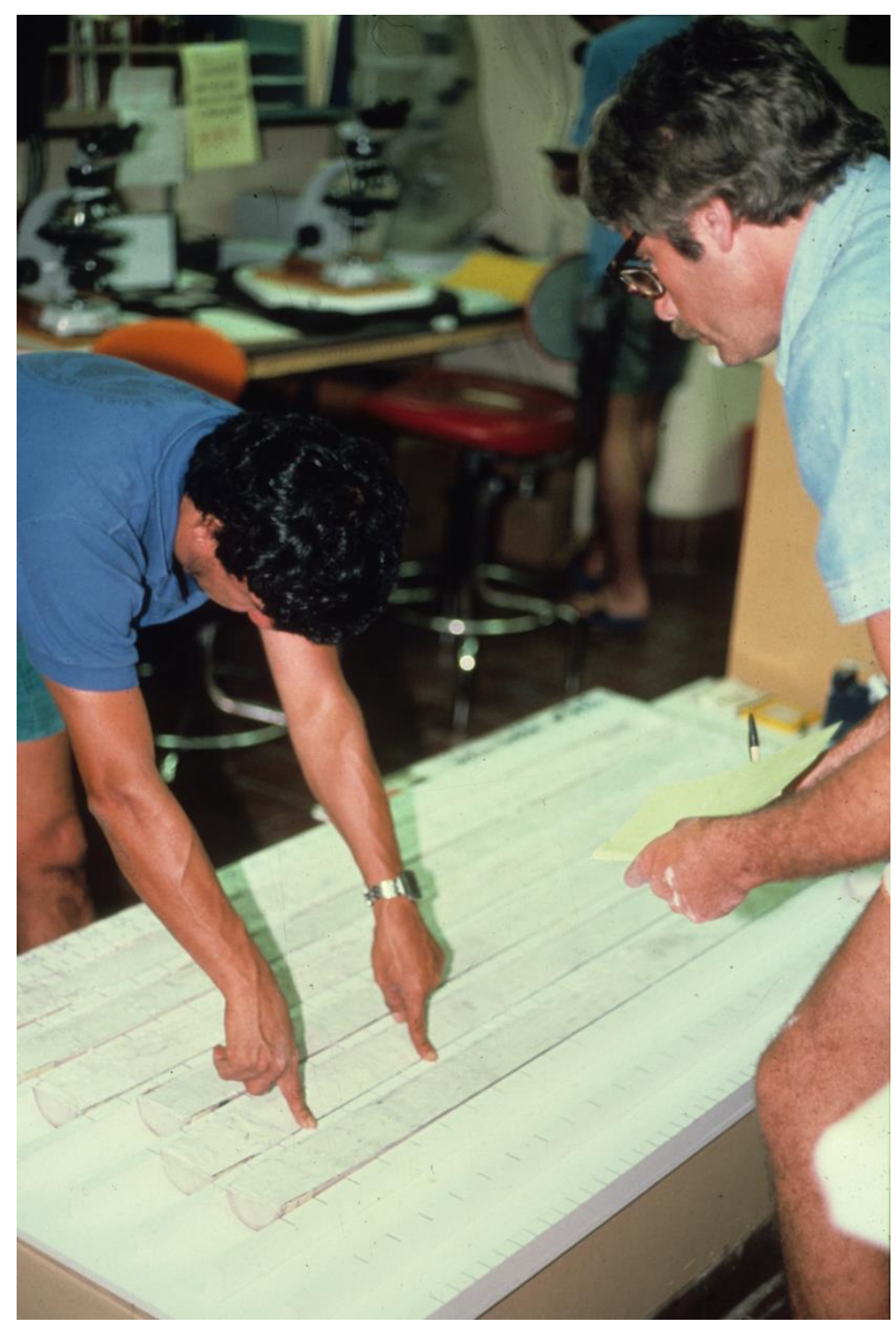

Fig. 2. Cam Nelson (right) inspecting fresh cores with a colleague on Glomar Challenger in January, 1983, during the Leg 90 cruise. Photo courtesy of Cam Nelson. 


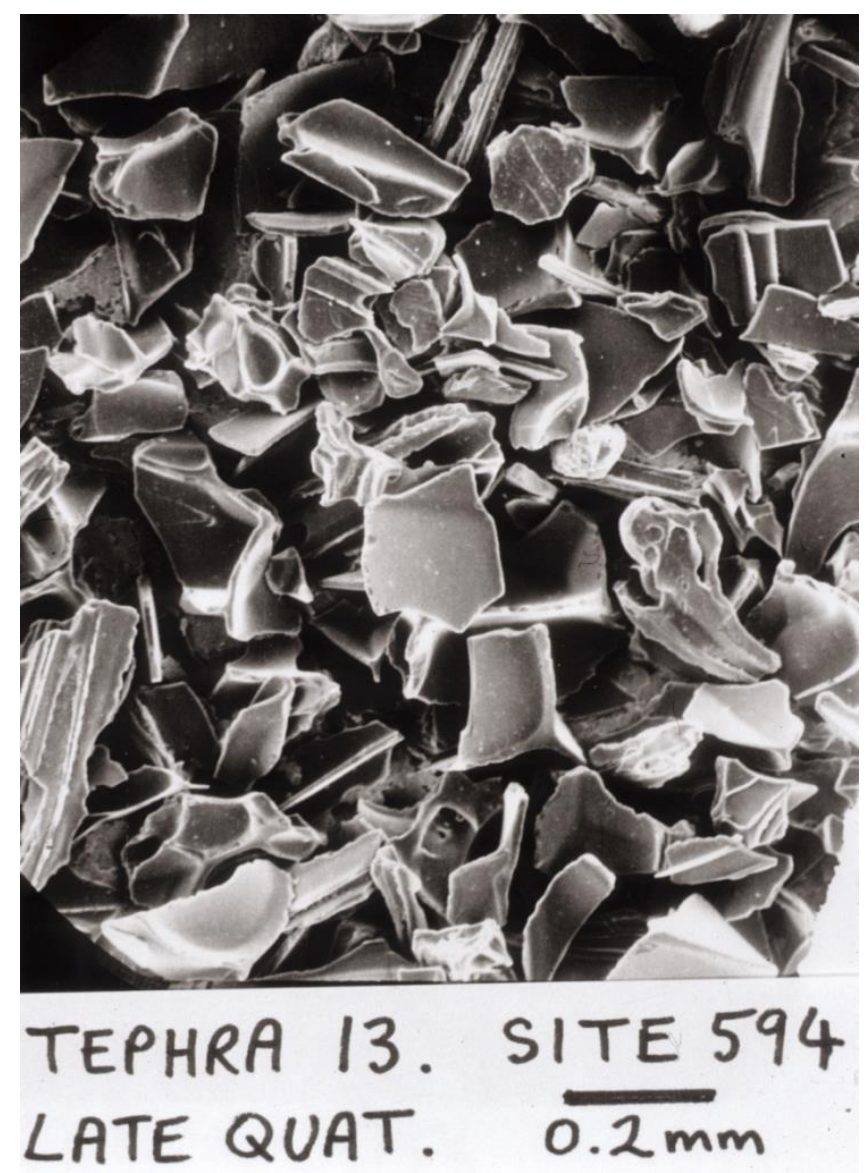

Fig. 3. Micrograph of glass shards of visible tephra no. 13 (after Nelson et al. 1985b, p. 1173) from DSDP site 594, subsequently identified by Nelson (1988) as a correlative of the very widespread and voluminous Whakamaru-caldera derived 340,000-year-old Rangitawa tephra (formerly known also as Mt Curl tephra, Ohinewai ash, and Hamilton ash ' $\mathrm{H} 1$ ' bed), which was deposited from a super-eruption near the end of Marine Oxygen Isotope Stage 10 (Kohn et al. 1992; Pillans et al. 1996; Lowe et al. 2001; Holt et al. 2010; Matthews et al. 2012; Alloway et al. 2013). Micrograph courtesy of Cam Nelson (his handwritten notes reflect the pre-digital era). 


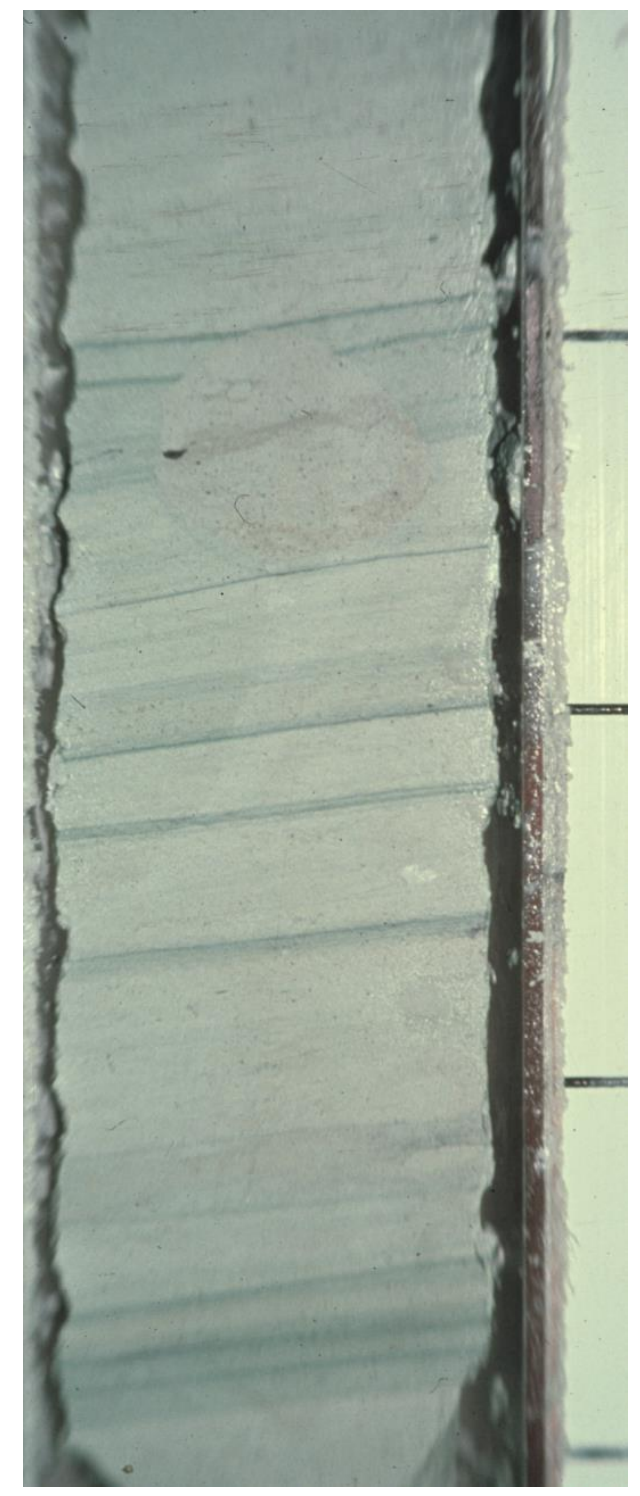

Fig. 4A. Around 12 pale-green laminae (thin dark layers, some composites) in part of a core from DSDP site 599 from central Lord Howe Rise, Tasman Sea (from Gardner et al. 1985, p. 1147). Core shown is about $20 \mathrm{~cm}$ long (scale marks on right at $5-\mathrm{cm}$ intervals). The laminae comprise mainly authigenic smectite and tend to occur in association with iron sulphide. There is a general correspondence between the occurrence of laminae and the presence of volcanic glass in smear slides, hence their identification as diagentically altered remnant tephra layers (Gardner et al. 1985). Indistinct circular feature near top between the first and third laminae (cutting though the second lamina) is an infilled burrow. Photo courtesy of Cam Nelson. 


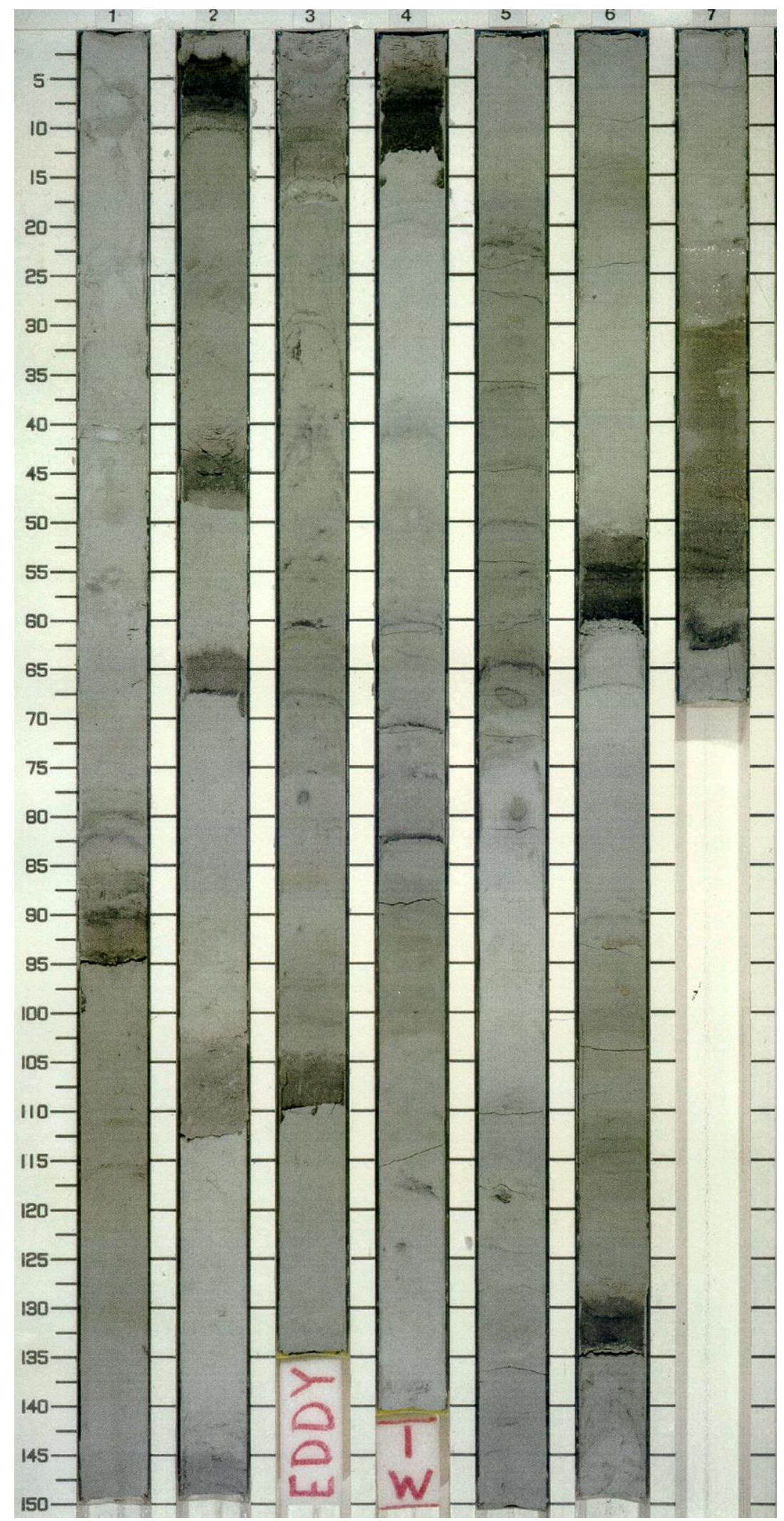

Fig. 4B. Tephra beds (dark coloured) in nanofossil ooze (pale coloured) in cores from ODP site 1124 ( $4000 \mathrm{~m}$ water depth) due east of central North Island, New Zealand. Scale at left in centimetres. Photo courtesy of Lionel Carter (from Alloway et al. 2013, p. 298, with permission from Elsevier). 